\title{
AKTUALISASI WHOLE LANGUAGE SEBAGAI PENDEKATAN PEMBELAJARAN BAHASA PADA ANAK USIA DINI
}

\author{
Ida Yeni Rahmawati' ${ }^{1}$, Raya Nurlianharkah ${ }^{2}$, Cahyo Hasanudin $^{3}$, M. Fadlillah ${ }^{4}$ \\ ${ }^{1,2,4}$ Fakultas Keguruan dan Ilmu Pendidikan, Universitas Muhammadiyah Ponorogo \\ ${ }^{3}$ Fakultas Pendidikan Bahasa dan Seni, IKIP PGRI Bojonegoro \\ 1email: Idayenir@umpo.ac.id \\ 2email: rayanurlianharkah@gmail.com \\ ${ }^{3}$ email: cahyo.hasanudin@ikippgribojonegoro.ac.id \\ 4email: Fadly_ok@yahoo.co.id
}

\begin{abstract}
Language skills in early childhood has different levels of speed. Many cases occur such as school-age children who have speech delays. Factors that can affect both the parenting style of parents, the methods used in schools and even environmental factors. The method of delivering learning in schools has an important role in improving children's language development. Whole language is a natural approach in language learning. This research aims to describe and explain the actualization of whole language as an approach to early childhood language learning. Literature study is the research method used in this research. Literature studies, whether in the form of books, notes, or reports on the results of previous research, are materials used for the research process. The result of this analysis is to describe the form of application, weaknesses and strengths of language teaching using a whole language approach that can be modified according to the conditions in each school. Based on data that has been found that language skills in early childhood can increase naturally because this whole language approach in principle integrates learning with contextual matters. The four aspects of language skills, namely listening skills, reading skills, writing skills and speaking skills are also integrated in one activity to find out where students' weaknesses are in learning languages.
\end{abstract}

Keywords: Whole language, language learning approach, early childhood

Abstrak: Kemampuan berbahasa pada anak usia dini memiliki tingkat kecepatan yang berbedabeda. Banyak kasus yang terjadi seperti anak usia sekolah yang memiliki keterlambatan berbicara. Faktor yang dapat mempengaruhi baik dari pola asuh orang tua, metode yang digunakan di sekolah bahkan faktor lingkungan. Metode penyampaian pembelajaran di sekolah memiliki peran penting dalam peningkatan perkembangan bahasa anak. Whole language merupakan suatu pendekatan alamiah dalam pembelajaran bahasa. Penelitian ini bertujuan untuk mendeskripsikan dan menjelaskan tentang aktualisasi whole language sebagai sebuah pendekatan pembelajaran bahasa anak usia dini. Studi kepustakaan adalah metode penelitian yang digunakan dalam penelitian ini. Studi literatur, baik berupa buku, catatan, maupun laporan hasil penelitian terdahulu merupakan bahan yang digunakan untuk proses penelitian. Hasil dari analisis ini adalah memaparkan mengenai bentuk penerapan, kelemahan dan kelebihan pengajaran bahasa menggunakan pendekatan whole language yang dapat dimodifikasi sesuai dengan kondisi di masing-masing sekolah. Berdasarkan data-data yang telah ditemukan bahwa kemampuan berbahasa pada anak usia dini dapat meningkat secara alamiah karena pendekatan whole language ini pada prinsipnya mengintegrasikan pembelajaran dengan hal-hal yang kontekstual. Keempat aspek keterampilan berbahasa yakni keterampilan menyimak, keterampilan membaca, keterampilan menulis dan keterampilan berbicara pun diintegrasikan pada satu kegiatan guna mengetahui letak kelemahan siswa dalam belajar bahasa.

Kata kunci: Whole language, Pendekatan pembelajaran bahasa, Anak usia dini 


\section{PENDAHULUAN}

Pendidikan untuk anak usia dini merupakan suatu tanggung jawab bersama. Anak dalam hal ini diibaratkan seperti gelas kosong yang tentunya siap untuk diisi air. Air yang dimaksud di sini adalah berupa wawasan maupun pengetahuan yang dapat mengembangkan kemampuan siswa dalam hal ini lebih dikhususkan pada aspek perkembangan bahasa. Pada masa ini keemasan ini sangat tepat dimanfaatkan untuk menstimulasi seluruh aspek dalam merangsang tumbuh kembang pada anak usia dini. Awal pertumbuhan anak sangat penting, di mana pada masa ini perkembangan otak sangat bagus untuk distumulus dengan hal-hal yang tentunya dapat mendukung tumbuh kembang anak. Berdasarkan Permendikbud Nomor 146 tahun 2014 tentang kurikulum 2013 pendidikan anak usia dini, pasal 1 yang disampaikan bahwa pendidikan anak usia dini selanjutnya disingkat PAUD, merupakan suatu upaya pembinaan yang ditujukan kepada anak sejak lahir sampai dengan usia 6 (enam) tahun yang dilakukan melalui pemberian rangsangan pendidikan untuk membantu pertumbuhan dan perkembangan jasmani dan rohani agar anak memiliki kesiapan dalam memasuki pendidikan lebih lanjut.

Tahapan dalam memberikan stimulus atau rangsangan kepada anak ini secara tidak langsung juga dapat membantu pertumbuhan dan perkembangan jasmani dan rohani supaya anak -anak siap dalam mengahadapi kenaikan jenjang pendidikan pada tahap berikutnya. Untuk menunjang perkembangan anak, diperlukan pendidikan, pengasuhan, dan pengawasan yang baik. Salah satu perkembangan yang penting pada anak adalah perkembangan bahasa.

Dalam praktiknya, ketika mengajar pada anak utamanya ketika usia dini (0-6) tahun hendaknya menggunakan pendekatan pengajaran yang menyenangkan dan tercapainya tujuan pembelajaran. Salah satu pendekatan dalam pengajaran bahasa yakni pendekatan yang menitikberatkan pada pengintegrasian keempat aspek keterampilan yang disebut dengan whole language. Prinsip dasar penerapan pendakatan ini ialah dengan mengintegrasikan secara utuh segala aspek pengembangan bahasa didukung dengan teknik pengajaran yang menyenangkan. Secara utuh di sini maksudnya ialah pengintegrasian keempat aspek pembelajaran tersebut dilakukan secara terpadu atau tidak terpisah-pisah. Selain hal tersebut, prinsip utama dalam penerapan whole language ini juga pada aspek teknik atau cara belajar anak. Cara belajar pada anak usia dini yang menekankan pemahaman materi secara aktif serta dapat menguasai konsep menjadi lebih mudah dan cepat. Dalam hal ini, anak tentunya diharapkan mampu belajar secara langsung dengan arahan bahasa target yang digunakan dalam keseharian.

Pada pendekatan ini, kehadiran atau peran dari orang tua juga menjadi salah satu faktor pendukung keberhasilan. Orang tua merupakan guru bagi anak-anak ketika di rumah. Dalam hal ini, orang tua diharapkan juga mau dan mampu untuk mengenal kurikulum dan pembelajaran yang diberikan kepada anak. Pengajar dalam hal ini guru hendaknya dapat berkomunikasi dengan baik dengan orang tua dalam rangka menyamakan persepsi di dalam mendukung perkembangan anak. bentuk dari monitoring kegiatan ini, tidak hanya di lakukan di sekolah melainkan juga dapat dilakukan melalui mengunjungi ke rumah siswa. Dengan demikian, kerjasama antara guru dan wali murid dapat terjalin dengan baik 
untuk membantu dalam meningkatkan tumbuh kembang anak.

Pada hakikatnya pembelajaran bahasa pada anak ditekankan pada kemampuan berkomunikasi. Kemampuan berkomunikasi yang dimaksudkan di sini ialah dengan belajar mengungkapkan maksud atau tujuan yang ingin disampaikan sesuai dengan konteks lingkungan atau konteks yang dibutuhkan. Pembelajaran bahasa pada tingkat anak usia dini adalah mengarahkan anak agar dapat mengungkapkan suatu hal yang diinginkan, dipikirkan dan dirasakan menggunakan bahasa yang baik, santun, dan dapat dimengerti. Tentunya pengajaran tersebut harus menggunakan pendekatan pengajaran bahasa yang tepat agar dapat diterima oleh anak dengan baik.

Menurut Howard Gardner dalam Fadlillah (2018;142), terdapat delapan kecerdasan pada anak, salah satunya adalah kecerdasan linguistik atau berbahasa. Kecerdasan dalam kebahasaan atau linguistik ini meliputi kepekaan pada bunyi, struktur, makna, fungsi kata dan bahasa. Bahasa pada dasarnya merupakan hal yang penting bagi kehidupan sehari-hari. Kemampuan anak dalam berkomunikasi sangat dipengaruhi dari kemampuan berbahasanya. Kemampuan bahasa yang baik tentu akan semakin memudahkan anak dalam menyampaikan ide atau gagasan bahkan mampu mengekspresikannya dengan baik kepada orang lain. Komunikasi dalam hal ini dibagi menjadi dua jenis, yaknik komunikasi positif dan komunikasi negatif. Komunikasi positif di sini berupa penggunaan kosa kata yang santun, baik dan sesuai dengan konteks. Sedangkan, komunikasi negatif biasanya adanya penggunaan pilihan kosakata yang kurang baik atau kurang sopan. Dengan demikian, pembiasaan penggunaan bahasa yang sopan, baik dan santun pada anak usia dini harus digalakan sedari dini. Hal ini bertujuan, agar anak menjadi terbiasa menggunakan bahasa atau pilihan kata yang baik, sopan dan santun. Anak merupakan harapan bangsa, tunas bangsa yang nantinya akan ditunggu kontribusinya untuk negara, melalui penggunaan bahasa yang baik tentu akan mencerminkan karakter bangsa yang baik pula. Bahasa memiliki peran sentral dalam perkembangan intelektual, sosial, dan emosional peserta didik. Salah satu pendekatan yang dapat diterapkan untuk perkembangan bahasa anak adalah pendekatan whole language.

Pendekatan whole language ini dikembangkan oleh John Dewey. Pada pendekatan ini menekankan pada konsistensi terhadap pemahaman anak, khususnya pada pembelajaran, sejalan dengan pemaparan Weaver, (2003:3). Pendekatan ini pada dasarnya cenderung pada penerapan pembelajaran secara alami. Hal ini didukung dengan suasana yang menyenangkan dan tanpa adanya paksaan. Dengan demikian, pemelajar dapat belajar dengan nyaman dan penuh dengan keriangan. Ada pakar lain yang berpendapat yakni Eisele dan Weaver, yang menyatakan bahwa pendekatan whole language ini adalah teknik dalam pembelajaran bahasa. Pembelajaran bahasa di sini tidak hanya dipusatkan pada satu hal tertentu melainkan pada aspek bahasa lisan maupun bahasa tulis. Dengan demikian, secara terintegrasi empat aspek keterampilan berbahasa pun menjadi prinsip utama dalam penerapan pendekatan ini. Keempat keterampilan tersebut dapat dikembangkan dengan menciptakan lingkungan yang nyaman artinya lingkungan tersebut mendukung anak untuk belajar bahasa. Lingkungan yang mendukung di sini tentunya dengan menciptakan ruangan yang penuh dengan buku, tulisan, maupun gambar yang tentunya dapat menstimulus perkembangan bahasa anak. 
Whole language diciptakan pada tahun 1980-an oleh pendidik Amerika Serikat yang peduli dengan seni pengajaran membaca dan menulis dalam bahasa asli. Menurut Brenner dalam Carlo, De, J.E "whole language is a way of teaching pre reading, reading and other language skill thourgh all process that involve language, writing, talking, listening to stories, creating stories, art work and dramatic play as through more traditional path ways". Berdasarkan pendapat tersebut maka dapat disimpulkan bahwa pendekatan ini dapat digunakan untuk mengajar khususnya pra baca, membaca permulaan, menulis, mendengarkan cerita, mengarang cerita, karya seni, bermain drama dan lain sebagainya.

Whole language ini muncul sekitar tahun 1980 oleh pendidik di Amerika Serikat. Menurut Brenner dalam Carlo, De, J.E "whole language is a way of teaching pre reading, reading and other language skill thourgh all process that involve language, writing, talking, listening to stories, creating stories, art work and dramatic play as through more traditional path ways"'(Carlo, De, J.E, 1995:88).

Whole language juga dapat dimaknai sebagai sebuah pendekatan pengajaran bahasa yang lebih menekankan pada aspek kontekstual, logis, kronologis dan komunikatif serta bermakna. Pendekatan ini pada umumnya sudah banyak yang mengenal dan tentunya mengimplementasikannya khususnya pada negara-negara maju. Hal ini dijadikan sebagai sebuah keyakinan dapat memberi dampak yang signifikan terhadap pendidikan anak usia dini khususnya pada aspek bahasa. Hal ini diyakini karena di dalam pendekatan ini menekankan pengajaran bahasa yang kontekstual, logis, kronologis dan juga komunikatif. Hal-hal inilah yang saat ini dibutuhkan oleh pemelajar di Indonesia pada umumnya dan pada pendidikan anak usia dini pada khususnya dalam rangka menumbuhkan jiwa yang kritis, kreatif dan inovatif.

Dalam pendekatan ini, berulangulang ditekankan bahwa pada prinsipnya pendekatan pengajaran menggunakan whole language ini ditanamkan secara alami pada saat pembelajaran dengan suasana yang menyenangkan, tidak dipaksa dan tanpa secara terus menerus mengkritik. Paham yang mendasari pendekatan whole language ini ialah paham contructivism. Pada paham ini dinyatakan bahwa peserta didik dapat secara mandiri membentuk pengetahuannya dengan adanya peran aktif yang dilakukan saat pembelajaran secara utuh dan terpadu. Guru dalam hal ini bertindak sebagai fasilitator, dengan demikian suasana pembelajaran dibentuk supaya siswa lebih aktif. Di sisi lain, melalui pendekatan ini, peserta didik mendapatkan latihan dalam bertanggung jawab dan mandiri dalam proses pembelajaran.

Whole language merupakan sebuah pendekatan pembelajaran bahasa dengan prinsip kesatuan yang utuh dalam penyajian pengajaran bahasa pada anak usia dini. Pada pendekatan ini, terintegrasi dan terinternalisasi secara tidak terpisah dengan kurikulum pembelajaran. Hal ini tentunya jika ditinjau dari beberapa aspek kurikulum 2013 yang berlaku saat ini khususnya untuk pendidikan anak usia dini tentu sangat sesuai. Literasi sejak usia dini, secara tidak langsung sudah terintegrasi di dalam konsep pendekatan ini. Oleh karena itu, melalui pendekatan ini, proses pembelajaran berbahasa dapat secara menyeluruh tercapai dengan hasil yang baik karena didukung dengan adanya kurikulum yang sejalan dengan pendekatan ini. Berbicara merupakan suatu kegiatan untuk menyampaikan pesan melalui bahasa lisan. Sedangkan, tujuan utama pemelajaran berbicara di taman kanak-kanak adalah 
untuk mengenalkan bahasa, menambah kosakata, serta agar anak mampu menyampaikan perasaannya secara lisan menggunakan bahasa yang baik. penerapan pada pembelajaran kegiatan yang dapat dilakukan adalah menceritakan pengalaman yang mengesankan, mengungkapkan pengalaman pribadi, bermain peran, diskusi, dan lain sebagainnya.

Menurut Rafiuddin dan Zuchdi dalam Maulida, dkk., (2020) terdapat strategi pembelajaran bahasa melalui pendekatan whole language yang ditinjau dari aspek guru dan siswa:

Pertama, pencelupan (immersion); Guru hendaknya menciptakan lingkungan yang memungkinkan pembelajaran dapat terlaksana dengan baik. Program celup dalam kegiatan pembelajaran sehari-hari dapat dilakukan dengan mencotoh bahasa guru yang baik, bahasa teman sebaya, bahasa buku-buku, percakapan informal, bahasa yang didapat dari lirik lagu dan lain sebagainya.

Kedua, demonstrasi Strategi ini dilakukan dengan guru terlibat dalam peragaan pemakaian bahasa sebagai sumber pengayaan dan data bagi pembelajar dalam memformulasikan struktur kalimat, mengembangkan makna dan bahasa untuk digunakan dalam kehidupan sehari-hari.

Ketiga, Keterlibatan, yaitu semua komponen baik pendidik, lingkungan, serta peserta didik harus terlibat secara bersamasama.

Keempat, harapan, pada tahapan ini, kegiatan pembelajaran bahasa dapat sejalan dengan pola atau fase perkembangan peserta didik, dengan demikian tujuan pembelajaran pun dapat tercapai.

Kelima, tanggung jawab, pada fase ini, melalui pemberian kesempatan, kepercayaan, dan tanggung jawab untuk menentukan apa yang dipelajari anak, menjadi sumber belajar untuk lebih bertanggung jawab pada anak usia dini.

Keenam, pemakaian, hal-hal yang dilakukan pada strategi ini adalah memahami bahasa, mencoba menggunakan bahasa, dan menentukan waktu penggunaan bahasa.

Ketujuh, aproksimasi, dalam proses pembelajaran terjadinya kekeliruan wajar adanya sehingga guru hendaknya tidak memaksakan kehendak.

Delapan, respons dan umpan balik, pada fase ini guru diharapkan dapat lebih aktif dalam menstimulasi pemelajar dengan percakapan, selain itu hal ini dapat menjadi model untuk mengembangkan sintaksis, semantik, dan pragmatik siswa. Dengan demikian, adanya respons dan umpan balik ini tentunya menjadi sebuah evaluasi pembelajaran bahasa yang lengkap.

Menurut Iskandar (2016) ada delapan komponen dalam pendekatan whole language, yaitu,

Pertama, reading aloud. Kegiatan membaca ini dilakukan oleh guru kepada siswanya. Guru membaca dengan keras dan intonasi yang baik. Reading aloud dapat dilakukan sekitar sepuluh menit dan bertujuan mengajak siswa untuk melaksanakan proses membaca secara keras dan berintonasi.

Kedua, jurnal writing. Setelah kegiatan membaca, siswa diharapkan untuk mampu belajar menulis. Siswa mampu menulis melalui buku pedoman atau buku lembar kerja siswa yang telah disiapkan oleh guru. Latihan menulis ini merupakan bentuk kelanjutan dari latihan membaca.

Ketiga, Sustained Silent Reading (SSR), yaitu kegiatan membaca dalam hati yang dilakukan siswa. Dalam hal ini siswa diberi kesempatan untuk memilih sendiri buku atau materi yang akan dibacanya.

Keempat, shared reading, kegiatan ini adalah membaca bersama, di mana setiap siswa tentu memiliki buku yang 
sama, dan guru tentunya memandu latihan membaca bersama ini supaya dapat secara serentak mengikuti kata demi kata yang ada dalam buku.

Kelima, guided reading, pada tahap ini adalah membaca terbimbing, di mana siswa dapat membaca dengan baik dipandu dengan guru. Guru di sini sebagai fasilitator, dan siswa tentunya yang harus lebih aktif dalam berlatih membaca.

Keenam, guided writing (menulis terbimbing), pada fase ini siswa tentunya berlatih menulis secara terbimbing. Guru di sini memberikan teknik menulis yang baik dan benar baik dari cara menulisnya sesuai dengan aturan dalam menulis yang baik dan benar.

Ketujuh, independent reading (membaca bebas), sedangkan pada fase ini anak dapat membaca secara mandiri mengenai materi yang disukainya atau diinginkannya. Kebebasan yang diberikan ini merupakan bentuk rekognisi terhadap kegiatan literasi, di mana anak berhak juga membaca memilih bacaannya sendiri secara bebas sesuai dengan yang dibutuhkannya.

Kedelapan, independent writing (menulis bebas), pada fase ini pada dasarnya hampir sama dengan kegiatan membaca bebas, bentuk dari rekognisi literasi, di mana siswa dibebaskan untuk mmbaca maupun menulis sesuai dengan yang diinginkan atau dibutuhkan, namun tentu saja dengan pengawasan atau kontrol baik dari guru maupun orang tua. Hal ini hendaknya tetap dapat dilakukan karena, anak usia dini hakikatnya secara alamiah belajar sambil bermain.

padapenerapannya di tingkat pendidikan Anak Usia Dini (AUD) tidak semua komponen di atas dapat digunakan. Seperti halnya bahwa pembelajaran anak usia dini adalah pembelajaran nyata dan belajar sambil bermain. Tujuan pembelajaran pada anak usia dini ini untuk mengembangkan bahasa adalah agar anak dapat mengutarakan perasaannya menggunakan bahasa yang baik serta menambah kosakata pada anak.

\section{METODOLOGI}

Metode penelitian serta teknik pengumpulan data yang digunakan adalah studi pustaka (Library Research). Penelitian kepustakaan menurut Sugiono dalam Hasanudin, dkk. (2021) menyatakan bahwa penelitian kepustakaan adalah teori, referensial dan studi literatur tentang budaya dan nilai-nilai moral. Dasar-dasar penelitian perpustakaan termasuk perpustakaan organisasi, jenis bahan yang tersedia, akses informasi dan strategi penelitian. Studi kepustakan adalah suatu penelitian yang dilakukan melalui mengumpulkan sejumlah informasi yang berkenaan dengan masalah dan tujuan penelitian oleh peneliti. Buku dalam hal ini, dianggap sebagai sumber data yang akan diolah dan dianalisis seperti banyak dilakukan oleh ahli sejarah, sastra, dan bahasa (Danial, 2009). Tujuan penggunaan metode penelitian studi pustaka ini adalah untuk menemukan sebuah masalah yang diteliti, mencari informasi yang relevan, mengaji teori-teori dasar yang relevan serta untuk memperdalam pengetahuan peneliti mengenai masalah dan bidang yang akan diteliti dari hasil riset terdahulu. Teknik pengumpulan data pada penelitian ini dilaksanakan dengan cara membaca, menelaah dan mencatat berbagai literatur atau bahan bacaan yang sesuai dengan pokok bahasan. Hal ini tidak secara langsung dijadikan sebagai acuan melainkan disaring terlebih dahulu, kemudian dituangkan dalam kerangka pemikiran secara teoretis. Pada teknik ini, digunakan sebagai bahan untuk membandingkan teori mengenai bentuk penerapan whole language, kelebihan dan kelemahan whole language dari berbagai penelitian terdahulu dengan penelitian 
terkini. Sedangkan, metode analisis data yang digunakan ialah metode deskriptif yaitu mendeskripsikan suatu gejala atau peristiwa yang tentunya memusatkan pada masalah yang aktual.

\section{HASIL DAN PEMBAHASAN}

Berdasarkan hasil analisis mendalam mengenai hasil penerapan pendekatan whole language bagi perkembangan bahasa anak usia dini tentu sangat signifikan, dibandingkan dengan adanya pendekatan konvensional. Hal ini sejalan dengan pendapat Rachmawati dan Ummah, dalam Sanusi, dkk (2020:38) yang menyatakan bahwa untuk meningkatkan proses pembelajaran siswa tentu dibutuhkan adanya sebuah strategi yang khusus untuk mendukung pencapaian pembelajaran siswa. Perkembangan bahasa anak dalam hal ini tentu akan mengalami perkembangan seiring dengan

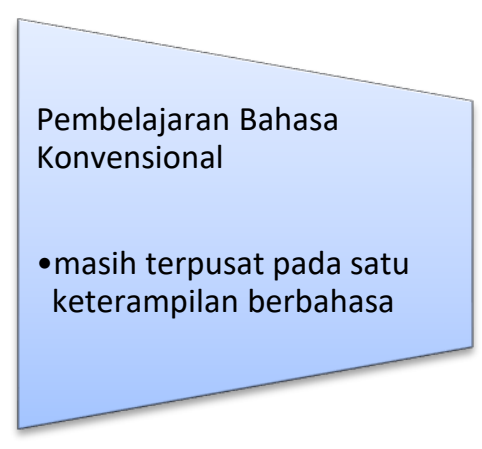

bertambahnya umur. Perkembangan umur anak di sini dapat memicu keterampilan berbicara dan berpikir anak tentunya. Sejalan dengan perkembangan hal tersebut, maka kemampuan anak dalam mengekspresikan keinginannya pun akan semakin terlihat jelas.

Perkembangan bahasa anak akan semakin terlihat ketika usia anak memasuki 5-6 tahun. Peningkatan kemampuan berbahasa anak dapat dilihat dari bertambahnya kosakata dan kemampuan anak dalam menyampaikan informasi baik kepada teman sebaya maupun kepada orang lain. Hal ini ditandai dengan penggunaan struktur kalimatnya yang benar, kata ganti dan kata kerja. Pada anak usia dini, rata-rata panjang kalimat yang digunak setiap percakapan mencapai 6-8 kata. Kemudian, untuk jumlah kosa kata yang digunakan pada anak usia dini kurang lebih sebanyak 2.500 kata.

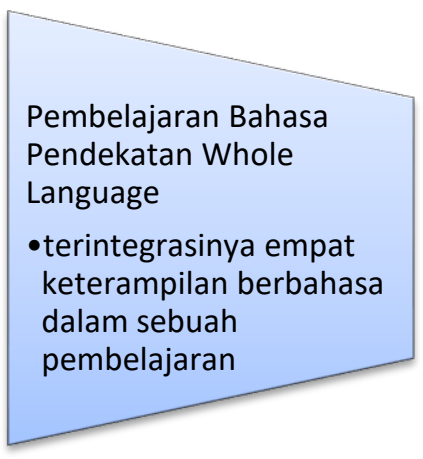

Bagan 1. Kondisi pembelajaran Bahasa

Berdasarkan bagan 1 mengenai perbandingan kondisi pembelajaran bahasa pada anak usia dini maka dapat dideskripsikan bahwa ketika sebuah pembelajaran masih menerapkan pendekatan konvensional, dengan menitik beratkan pada satu keterampilan saja maka hasil yang akan diperoleh tentunya kurang maksimal. Hal ini dipengaruhi terpusatnya satu keterampilan yang diterapkan dalam proses pembelajaran bahasa. Sedangkan, pada pembelajaran bahasa melalui pendekatan whole language, tentunya sudah terintegrasi dengan empat keterampilan berbahasa, yang tidak lain secara terpadu pembelajaran tersebut terintegrasi dengan pembelajaran bahasa yang kontekstual sehingga sangat relevan jika diterapkan pada era sekarang. Di era yang cukup pesat seperti saat ini, pengajaran bahasa menjadi salah satu tolok ukur kemampuan anak dalam memahami konteks yang tentunya 
memicu anak untuk berpikir kritis dan kreatif.

Berdasarkan hasil penelitian terdahulu menyampiakan bahwa penerapan pengajaran bahasa untuk anak usia dini faktanya di lapangan masih sebatas permintaan dari orang tua wali dalam memenuhi target. Hal ini dipicu adanya beberapa sekolah dasar menghendaki anak untuk mampu membaca dan menulis ketika memasuki sekolah dasar favorit. Oleh karena itu, banyak orang tua yang meminta kepada guru supaya menambah jam pembelajaran atau jam khusus untuk belajar membaca dan menulis. Hal ini memicu guru untuk mengingkari kodrat pembelajaran bahasa yang seyogyanya dapat diterapkan dengan pendekatan yang menyenangkan yakni belajar sambil bermain. Hal ini tentu diabaikan begitu saja, tanpa memperhatikan dampak psikologis bagi peserta didik. Berdasarkan studi kasus tersebut maka hendaknya dapat dijadikan sebagai sebuah perenungan mengenai pendekatan yang sesuai untuk mengembangkan empat aspek keterampilan berbahasa anak secara terintegrasi.

Keterampilan membaca permulaan, menulis permulaan, menyimak dan berbicara ini merupakan rangkaian pembelajaran bahasa yang tentunya sangat sesuai dikenalkan pada anak usia dini menggunakan pendekatan whole language. Pada dasarnya banyak orang yang belum mengetahui mengenai penerapan pendekatan whole language terutama pada sekolah-sekolah yang masih menggunakan metode atau pendekatan yang konvensional.

Pendekatan whole language dapat meningkatkan perkembangan bahasa anak, karena pada praktiknya adalah dengan pembelajaran yang menyeluruh serta tidak terpisah pada empat aspek keterampilan berbahasa dapat membantu peserta didik dalam meningkatkan perbendaharaan kosakata serta pemahaman konteks dalam kehidupan sehar-hari. Empat aspek keterampilan tersebut meliputi keterampilan menulis, membaca, menyimak dan berbicara, menurut Tarigan, (2016). Hal ini sejalan dengan pemikiran Hidayah, (2014) yang menjelaskan bahwa whole language merupakan suatu cara atau teknik atau pendekatan dalam mengajar pra membaca, menulis, mendengarkan cerita, mengarang cerita, karya seni dan bermain drama. Dalam pengajaran bahasa khususnya pada pendidikan anak usia dini, guru haruslah memperhatikan teknik pengajaran bahasa yang digunakan sejalan dengan kaidah bahasa dan dapat disajikan secara utuh dalam situasi yang nyata (autetik) dan bermakna kepada peserta didik. Hal ini seyogyanya dapat diimplementasikan dalam kehidupan sehari-hari oleh guru guna dijadikan sebagai panutan bagi seluruh siswa dalam menggunakan pilihan kata yang baik dan sopan. Hal ini sejalan dengan pendapat Krashen dalam Fauzi dan Basikin (2020) dengan adanya tuntutan pembelajaran bahasa komunikatif, maka guru di sini diharapkan untuk mampu melaksanakan proses pembelajaran sesuai dengan karakteristik anak usia dini. Disisi lain, kecakapan dalam berbahasa di sini pada dasarnya dilandasi oleh fitrah dan latihan yang dilakukan oleh seseorang agar memiliki kecakapan hidup yang disesuaikan dengan yang dibutuhkan, hal ini sejalan dengan yang dipaparkan Munandar dalam Fauzi dan Basikin (2020). Bahasa dalam hal ini diartikan sebagai bentuk pendidikan yang terdiri dari berbagai kata dengan kaidah dalam memvariasikan atau menggabungkan katakata tersebut menjadi sebuah teks yang bermakna, Santrock dalam Fauzi dan Basikin (2020).

Perkembangan kemampuan membaca permulaan anak disesuaikan dengan tahapan umur anak, menurut Mashito dalam Ayunita (2019) menyataka 
bahwa anak pada usia 1 sampai 3 tahun, anak sudah mulai mampu menangkap banyak kata dari gambar-gambar dan permainan. Pada usia 3 sampai 4 tahun, kemampuan anak masih pada fase belajar membaca permulaan, serta memperoleh kemampuan, membunyikan kata-kata, menerjemahkan huruf menjadi bunyi dan keahlian membaca lainnya. Selanjutnya, dalam pengajaran bahasa pada anak usia dini ini terdapat tiga komponen utama dalam kegiatan membaca yaitu: (1) rekaman yang tertuju pada kata-kata dalam kalimat, (2) pengkodean yang ditujukan pada arti dari serangkaian grafik dalam kata-kata, dan (3) makna, yakni pengertian kata, Rahim dalam Fauzi dan Basikin (2020). Berdasarkan hasil dari penelitian terdahulu bahwa pengajaran bahasa pada anak usia liam sampai enam tahun ini berada pada fase membaca permulaan dan menulis permulaan. Pada periode ini anakanak melakukan kegiatan pencatatan dan penguraian kode atas bacaan yang diberikan kepada mereka, menurut Cahyani dalam Fauzi dan Basikin (2020). Dalam kondisi ini, guru harus memastikan bahwa anak mampu menguasai kemampuan dasar antara lain, mampu untuk membedakan pendengaran, visual, hubungan simbol suara, persepsi, bahasa lisan, membangun latar belakang yang bermakna, interpretasi gambar, kemampuan merangkai, dan penguasaan bahasa lisan dan literasi.

Pada hakikatnya bahwa pengajaran bahasa ini pada prinsipnya dilakukan secara bertahap, baik pada penerapan keterampilan membaca maupun menulis. Hal ini sesungguhnya saling berkaitan dengan indikator yang digunakan sebagai penilaian kemampuan membaca anak. Penilaian tersebut meliputi kemampuan dalam membaca khususnya dalam pengenalan huruf (bunyi), makna dan pemahaman makna dalam konteks bacaan.
Bentuk Penerapan Pendekatan Whole Languange antara lain pertama kegiatan pra kondisi ialah dengan mengondisikan peserta didik agar menyiapkan diri dalam belajar bahasa yang santun, toleran dan halus. Pada tahapan ini kegiatan yang dapat dilakukan ialah menyimak dan merespons. Dalam hal ini, supaya siswa ikut berpartisipasi aktif dalam masalah urgensi di lapangan mengenai penggunaan bahasa yang santun. Selanjutnya, pembelajaran merupakan tahapan setelah pra kondisi. Pada tahapan ini, guru diharapkan dapat mengemukakan kosakata santun, toleran dan halus. Kegiatan konkretnya adalah guru mampu mengembangkan pengajaran bahasa tersebut melalui gerak, suara, sesuai dengan kaidah dalam kebahasaan. Kemudian, pemelajar pada tahap ini ialah menyimak, menghayati, menirukan kalimat, nada, suara dan mampu menirukan gerakan yang telah dicontohkan oleh gurunya.

Selanjutnya, pada fase berikutnya pengecekan suasana pembelajaran. Pengecekan ini dilakukan oleh guru untuk mengetes suara kelas. Hal ini dilakukan untuk pengamatan dan penghayatan akan gerak dan mimik suara yang dilakukan oleh peserta didik. Siswa pada tahapan ini mengikuti instruksi yang telah diberikan guru yakni dengan menirukan mimik, nada, suara dan gerakan. Selanjutnya, adalah tahap penguatan. Pada tahapan ini yang utama ialah tentang pengetahuan bahasa meliputi nilai, norma yang melekat pada kosakata dengan memberikan penekanan momen tertentu yang dianggap penting. Kegiatan siswa dalam hal ini ialah dengan merespons, memberikan jawaban dan menulis.

Tahapan evaluasi merupakan tahapan kelima, setelah memberikan penguatan. Pada tahapan ini guru diharapkan dapat mengajukan pertanyaan kepada siswa melalui pertayaan singkat terhadap materi bahasa dan kesantunan, toleransi pada 
aspek bahasa yang diajarkan. Siswa dalam hal ini anak usia dini tentunya diajak untuk menjawab pertanyaan yang diajukan oleh guru melalui kosakata, gerak maupun mimik. Selanjutnya, pada tahapan ini guru mengarahkan siswa untuk bersama-sama menyimpulkan isi pembelajaran bahasa dan mengarahkan pada simpulan yang benar sesuai dengan tujuan atau harapan pembelajaran. Kegiatan menyimpulkan bersama-sama mengenai materi atau pokok bahasan pada hari itu dengan menggunakan bahasa yang bernilai pendidikan karakter, hal ini sejalan dengan pemaparan Anggareni, (2019).

Penerapan pendekatan whole language ini memiliki ciri khusus dalam pengajaran bahasa menurut Alamsyah dalam Hidayah, (2014) meliputi, (1) kelas tersebut biasanya dilengkapi dengan berbagai bahan yang dicetak, sebagai contoh gantungan dinding, gantungan pintu, dan sebagainya. (2) Guru dalam hal ini sebagai role model dalam pembelajaran, (3) siswa bekerja dan belajar sesuai dengan tingkat kemampuannya sebagai contooh siswa paud tentu kemampuannya juga disesuaikan dengan usia dan tingkat pembelajarannya, (4) siswa berbagi tanggung jawab dalam pembelajaran, (5) siswa selanjutnya terlibat aktif dalam pembelajaran bermakna, (6) siswa berani mengambil risiko dan bebas dalam bereksperimen, (7) siswa mendapat umpan balik yang positif dari guru maupun temannya.

Ditinjau dari aspek kelemahan dan kelebihan dari pendekatan whole langauage ini adalah sebagai berikut. Berdasarkan hasil penelitian Ganing (2017) menyatakan bahwa dengan menggunakan pendekatan whole language pada pengajaran bahasa menjadi lebih menyenangkan karena dapat dipadukan dengan berbagai permainan yang menyenangkan. Ini merupakan salah satu kelebihan dari penerapan pendekatan whole language. Di sisi lain berdasarkan hasil penelitian tindakan kelas menggunakan pendekatan ini juga mengalami peningkatan yang ditunjukan dengan perubahan prosentase dari siklus satu ke siklus dua, baik dari aspek memahami bahasa, mengungkapkan bahasa dan keaksaraan. Pendekatan ini diyakini mampu membantu merangsang kinerja otak kanan dan indra pengelihatan karena pada penerapannya yang dipadukan menggunakan permainanpermainan yang menyenangkan.

Pendekatan whole language juga diyakini dapat membantu dalam meningkatkan kemampuan membaca permulaan pada anak usia dini. Hal ini sejalan dengan penelitian yang telah dilakukan oleh Meha, Nehru, dan Adiyati (2014) yang menjelaskan bahwa hasil dari penelitian tindakan kelas menggunakan pendekatan whole language untuk meningkatkan kemampuan membaca permulaan anak mengalami peningkatan lebih dari 50\%. Pendekatan ini juga diyakini mampu mengubah suasana yang semula teacher center menjadi student center. Berdasarkann hasil penelitian tersebut maka tentunya dapat dijadikan sebagai cermin atau acuan dalam mengembangkan pengajaran bahasa pada anak usia dini. Di sisi lain, keberadaan suasana dan kondisi di dalam kelas juga disetting sedemikian rupa untuk menumbuhkan kebiasaan dan rasa nyaman di dalam kelas yang penuh dengan stimulus-stimulus untuk menyukai bahan bacaan guna meningkatkan kemampuan berbahasa. penambahan ruang baca atau pojok baca di sekolah tentu menjadi salah satu spot yang penting untuk menunjang terciptanya suasana yang mendukung untuk meningkatkan kebiasaan membaca atau menggemari bahan bacaan sejak usia dini. Hal ini sejalan dengan prinsip immersion bahwa ketersediaan bahan bacaan dapat 
mendukung tercapainya tujuan pembelajaran.

\section{SIMPULAN}

Whole langauge merupakan salah satu pendekatan dalam pembelajaran bahasa, yang dapat meningkatkan perkembangan bahasa pada anak usia dini. Hal ini tentu menjadi sebuauh terobosan baru dalam mengentaskan pembelajaran model konvensional. Dalam pendekatan pembelajaran ini tentu difokuskan pada pembelajaran yang menyenangkan dan utuh atau tidak terpisah-pisah. Keterampilan berbahasa seperti menyimak, berbicara, membaca permulaan, dan menulis permulaan tentunya diajarkan secara terpadu (integrated) sehingga peserta didik dapat mempelajari dan memahami bahasa secara keseluruhan, sebagai satu kesatuan yang utuh dengan cara yang menyenangkan. Berdasarkan hasil dari pembahasan tersebut maka dapat disimpulkan bahwa terdapat beberapa tahapan dalam mengimplementasikan whole language ini dalam pengembangan bahasa anak usia dini. Tahapan tersebut dimulai dari (1) pencelupan, di mana pada tahap ini bahasa yang diperoleh dari guru, buku dan lingkungan sekitar menjadi acuan anak, (2) demonstrasi yakni peragaan pemakaian bahasa yang dilakukan oleh anak, (3) keterlibatan, tentunya pada tahap ini keterlibatan semua pihak menjadi faktor pendukung perkembangan bahasa anak, (4) tanggung jawab, di mana pada fase ini anak diberikan kesempatan pada anak untuk bertanggung jawab akan hal yang dipilihnya, (5) membaca terbimbing, pada tahapan ini anak diharapkan anak mampu fokus pada buku yang dibacakan untuk anak di kelas, dengan adanya stimulus pembacaan buku ceritanya, anak diharapkan mampu memahami isi dari cerita tersebut, hal ini tentu dapat memicu daya kritis anak sejak usia dini, (6) menulis terbimbing, sedangkan pada fase ini anak diharapkan mampu menulis atau mengerjakan latihan berupa menulis pada lembar kerja masingmasing, (7) respons dan umpan balik, ini merupakan fase terakhir yang dapat dikolaborasikan pada tahapan penerapan pendekatan whole language dalam mengembangkan kemampuan berbahasa anak usia dini.

\section{DAFTAR PUSTAKA}

Anggareni, N. D. (2019). Pendampingan belajar bahasa Indonesia melalui pendekatan whole language di sekolah dasar negeri 020 Galang. Jurnal Minda Baharu, 3(2). 145-155. Retrieved from https://journal.unrika.ac.id/index.php/ MNDBHRU/article/download/2120/15 $\underline{19}$.

Ayunita, K. J. (2019). Peningkatan Kemampuan Membaca Permulaan Melalui Pendekatan Whole Language (Improving the ability of reading beginning Through Whole Language Approach). Jurnal Al-Athfal Jurnal Pembelajaran dan Pendidikan Anak Usia Dini, 1(2). 1-13. Retieved from http://jurnal.umpar.ac.id/index.php/ath fal/article/view/39.

Fadlillah. (2018). Bermaian dan Permainan Anak. Jakarta, Indonesia: Prenadamedia Group.

Fauzi, C. dan Basikin. (2020). The Impact Of The Whole Languag Approach Towards Children Early Reading and Writing In English. Jurnal Pendidikan Anak Usia Dini, 14(1), 94-108. Doi https://doi.org/10.21009/JPUD.141.07.

Ganing, N. Y., dan Kristiantari, M. R. (2017). Pengembangan kemampuan bahasa dengan pendekatan whole language melalui setting lesson study pada anak kelompok B TK Lab Undiksha Denpasar. Jurnal Pendidikan Guru Sekolah Dasar, Universitas Pendidikan Ganesha, 1(2). 
Hasanudin, C., Mayasari, N., Saddhono, K., \& Prabowo, R. A. (2021, February). IbisPaintX Apps in Creating Collaborative 3 D Learning media of Pop-Up and Movable Books. Journal of Physics Conference Series, 1764(1), 1-9. Doi https://doi.org/10.1088/1742$\underline{6596 / 1764 / 1 / 012131 .}$.

Hidayah, N. (2014). Pendekatan Pembelajaran Bahasa Whole Language. Jurnal Pendidikan dan Pembelajaran Dasar, 1(2), 292-305. Doi https://doi.org/10.24042/terampil.v1i2. 1322.

Meha, N, dan Roshonah, A. F. (2014). Implementasi whole language approach sebagai pengembangan model pembelajaran berbahasa awal anak usia 5-6 tahun di PAUD Non Formal. Jurnal Pendidikan, 15(2), 6882.

Doi https://doi.org/10.33830/jp.v15i2.415.2 $\underline{014}$.

Rahmawati, I. Y. (2018). Bahasa Indonesia Untuk Perguruan Tinggi. Ponorogo, Indonesia: Unmuh Ponorogo Press.

Santrock, J. W. (2016). Children (Thirteenth). New York: McGrawHill Education.

Sanusi, R., Dianasari, E. L., Khairiyah, K. Y., \& Chairudin, R. (2020). Pengembangan Flashcard Berbasis Karakter Hewan untuk
Meningkatkan Kemampuan Mengenal Huruf Anak Tunagrahita Ringan. Jurnal Pendidikan Edutama, 7(2), 37-46. Doi http://dx.doi.org/10.30734/jpe.v7i2.7 $\underline{45}$.

Tarigan, D. (2001). Pendidikan Bahasa dan sastra Indonesia Kelas Rendah. Jakarta, Indonesia: Universitas Terbuka.

Maulidia, C. R., Fadillah, F., \& Miranda, D. pengaruh pendekatan whole language terhadap kemampuan membaca permulaan usia 5-6 tahun tk mawar khatulistiwa. Jurnal Pendidikan dan Pembelajaran Khatulistiwa, 8(7), 748-759.. Retrieved from https://jurnal.untan.ac.id/index.ph p/jpdpb/article/view/34134.

Iskandar, N. M. (2016). Penerapan Pendekatan Whole Language untuk Meningkatkan Kemampuan Menulis Karangan Narasi dalam Pembelajaran Bahasa Indonesia di kelas IV Sekolah Dasar (skripsi, Universitas Pendidikan Indonesia, Indonesia). Retrieved from http://repository.upi.edu/23420/. 